\title{
THE ROLE OF BONDED LOGISTICS CENTER TO ESTABLISH INDONESIA AS THE HUB OF COLD CHAIN AND HALAL LOGISTICS BUSINESS
}

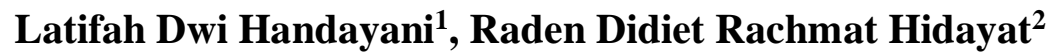 \\ 1. STMT Trisakti, 2. STMT Trisakti, \\ $\bowtie$ corresponding author: latifahldh@gmail.com
}

\begin{abstract}
The development of Cold Chain and Halal Logistics business is predicted to become one of the world's business opportunities in 2018. Indonesia as the largest Moslem's population in the world has a great opportunity to become the Hub of Cold Chain and Halal Logistics of the world. To establish the opportunity, the government has issued a facility in the form of Bonded Logistics Center or Pusat Logistik Berikat (PLB). The Bonded Logistics Center as the Government's Economic Policy Package was issued in September 2015. This is clarified by Regulation of the Minister of Finance No. 272 Year 2015 on Bonded Logistics Center as well as the Regulation of the Director General of Customs and Excise No. 1 of 2016. The Bonded Logistics Center (PLB) can be considered to help Indonesia become the Hub of Cold Chain and Halal Logistics business.

Keywords: bonded logistics center, cold chain, halal logistics concept
\end{abstract}

\section{Introduction}

The government is currently focusing on improving National Logistics. The Government of Indonesia through the Directorate General of Customs and Excise at the Ministry of Finance of the Republic of Indonesia has a solution by launching the Bonded Logistics Center. This facility prepared to encourage the creation of National and Regional Hubs in the Logistics business by providing a variety of flexibility ranging from revenue to goods expenditure, flexibility of activities to be carried out, the flexibility of ownership of goods, in addition to the flexibility of tax and customs facilities, as well as fast and easy service for 24 hours. The Bonded Logistics Center is a depot for and from abroad that brings the distance between business actors and raw material sources and lowers logistics costs and is part of the Government's Economic Policy Package of volume II issued by the government. This is clarified by Minister of Finance Regulation No. 272/PMK.04/2015 on Bonded Logistics and Government Regulation Number 85 of 2015 on amendment to Government Regulation Number 32 of 2009 on bonded landfill. Thus the Logistics Center is bound 
to its function that is to prepare inventory for industries that need raw materials and supporting materials in order to stabilize prices, guarantee supply and speed up the supply to the industry so that production planning and fulfillment of consumer orders can be more efficient (Kementerian Keuangan, 2015).

One of the fastest growing businesses in the world is Cold Chain and Halal Logistics. It is estimated that the Cold Chain and Halal business will reach peak occurs in 2018. Indonesia is the country with the largest number of Moslem population in the world. According to the Indonesian Statistics Center, the population of Moslems in Indonesia is currently around 207.176.162 people or about $87.18 \%$ of the population in Indonesia. Along with the growth of Moslem customers, awareness of Halal products is increasing. Halal products have become an important requirement for Moslems and other religions. However, what is happening now is that Halal industries in Indonesia are still struggling on Halal certification of products or brands and have not paid attention to the movement of goods to the hands of customers.

Height the current level of competition is encouraging companies to increasingly innovative and must be able to adapt to changes that occur. Install ebbed the company often occur along with changing conditions the environment (Umagapi et al., 2016). Toward external, Indonesia must be responsive to changes occurring at the global level (S, n.d.).

Based on the Regulation of the Director General of Customs and Excise of Republic of Indonesia No. Per-01/BC/2016 concerning to the Management of Bonded Logistics Center, hereinafter as Bonded Stockpiling is a building, place or area that meets certain requirements used to stock goods originated from outside customs areas and/or goods originated from elsewhere in customs areas, may be accompanied by 1 (one) or more simple activities within a certain period of time to be reissued (Direktur Jenderal, 2016). 
Basic Concept of PLB

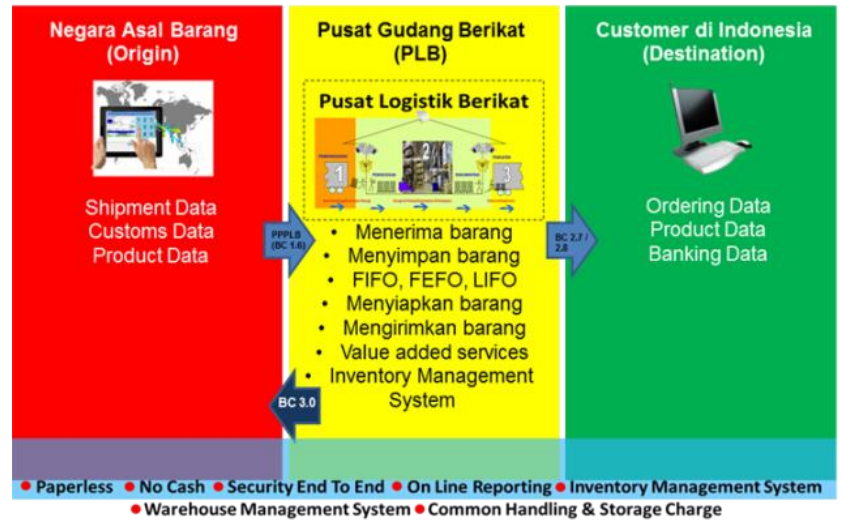

Figure 1. Basic Concept of PLB

Source: PT. Agility International (2016)

Cold Chain is a temperature-controlled Supply Chain. An unbroken Cold Chain is an uninterrupted series of storage and distribution activities which maintain a given temperature range. It is used to help extend and ensure the shelf life of products such as fresh agricultural products, seafood, frozen food, photographic film, chemicals, and pharmaceutical drugs (Widhiatmoko, 2017).

The benefits of Cold Chain such as (1) extend shelf life/length, (2) maintain fresh product appearance so it is possible to be marketed at higher price, (3) minimize the percentage of decay.

All company strives to keep product quality as per standards (Edi, n.d.).

Of the functions of logistics, the storage function should be paid attention as well. The aim is that the goods to be distributed stay in their quality and efficiency (Raden Didiet Rachmat Simarmata \& Len Togas, 2015).

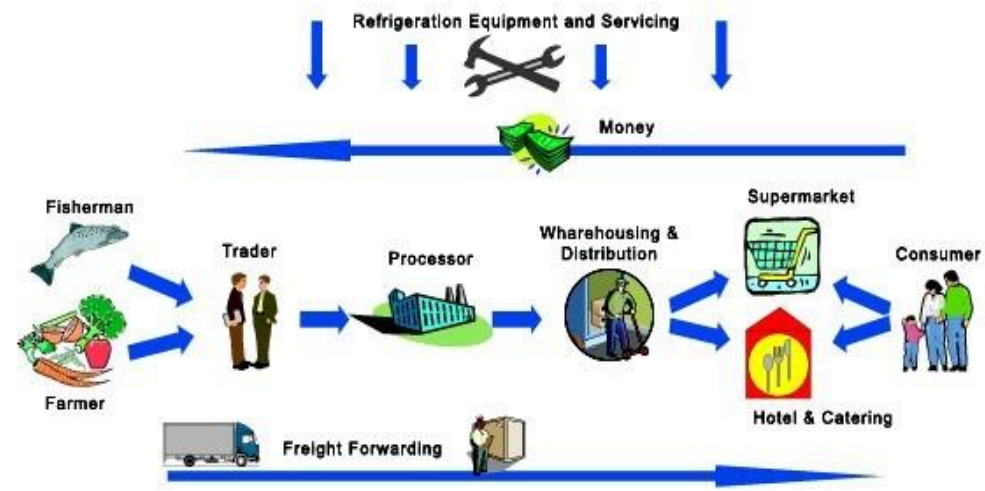

Figure 2. Cold Chain Management \& Process Source: PT. Multi Terminal Indonesia (2017) 
Halal Logistics is the process of managing the procurement, movement, storage and handling of materials, parts livestock and (semi) finished inventory both food and non-food (and related information \& documentation flows) through the organization and the Supply Chain in compliance with the general principles of Shariah Law (Hanafi, 2017).

Evolution of Halal business can be described as Moslem Company, Halal Products, Halal Supply Chain, Halal Value Chain (Tieman, 2011)

The "Halal" understanding can be interpreted according to the current needs, which are: (1) Universal foods means necessary for all humanity, not just for Moslems. Especially on the emphasis of the concept of health (Hygiene), Cleanliness (Cleanliness), Security (Safety) and Integrity, (2) Where this concept corresponds to Moslems' view of the meaning of "Halalan Toyyiban", (3) Animal cutting measures for Shari'a-compliant foodstuffs, (4) Selection of safe, clean and Shari'a food sources, (5) Commitment and declaration on the size of weight $\&$ measures to avoid contamination, (6) Good handling and storage according to the applicable law.

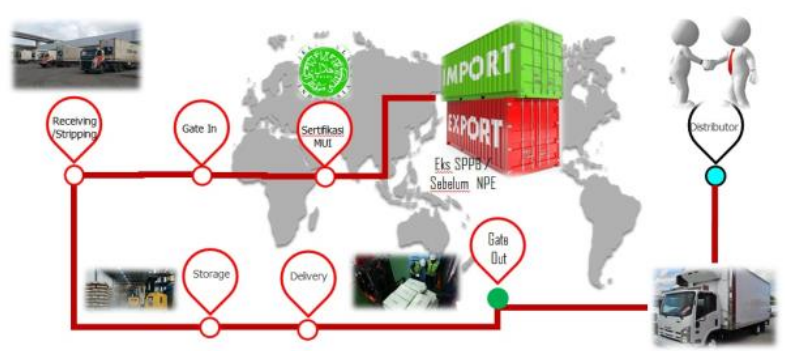

Figure 3. Flowchart Warehouse Domestic Halal Logistics \& Cold Storage Source: PT. Multi Terminal Indonesia (2017)

The ASEAN Freight Forwarders Association (AFFA) had conducted Southeast Asia Regional Cold Chain Logistics Science and Technology Forum in Taiwan on September $30^{\text {th }}$ to November $5^{\text {th }}, 2017$ and see the opportunity of Cold Chain and Halal Logistics business not only for Taiwan and ASEAN countries but also worldwide business. 


\section{Method}

The approach of this research is qualitative to give a clear picture of in depth description on how Bonded Logistics Center in Indonesia can be a Cold Chain and Halal Logistics business Hub. In this research, we just restricted about Halal Warehouse. Data collection is done through structured interview, semi-structured and in-depth interview and focus group discussion. The data analysis techniques used in this study employs an approach developed by Miles and Huberman that include (after data collection) data reduction, data separation from unfocused to detailed and others so that the data will reveal patterns or themes. Next is to display data (data display) that serves to help understand for advanced analysis of an information or event. The last process is the conclusion of the researchers based on the pattern and theme. Withdrawal conclusion is done continuously, that is done at the time of data reduction and data display (Miles, Huberman, \& Saldana, 2014).

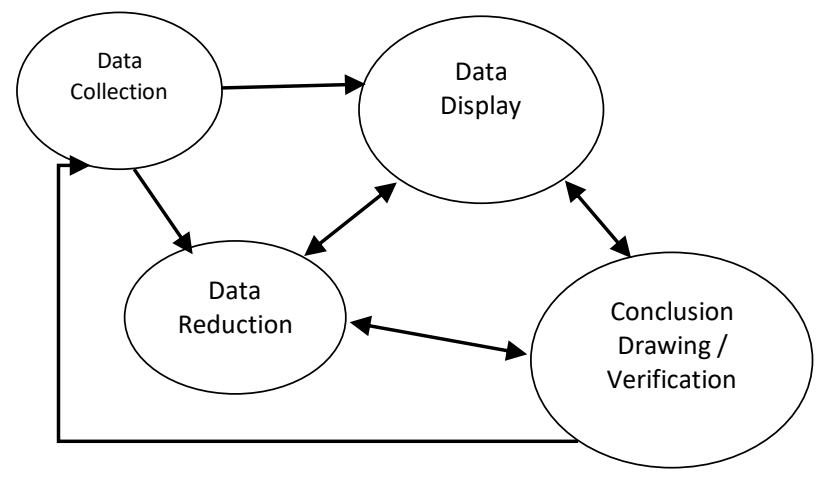

Figure 4. Data Processing Technique Source: Miles, Huberman, \& Saldana (2014)

\section{Result and Discussion}

Indonesia needs Halal products especially in Cold Chain. The concept is indispensable because Indonesia is a country with the largest Moslem population in the world. Currently, Moslem consumers in Indonesia have not secured by a Halal product guarantee in the Supply Chain. The distributions of halal products to consumers are not easily controlled. For example, meat products after being slaughter in halal way,do not yet have halal standards for Logistics to the consumer. Halal has the connotation as 
Healthy and Beauty for both Muslim and non-Muslim consumers. Although the majority of the population in the country of Thailand is not based on Moslem country, but Thailand has been the Hub for Halal Fashion. Halal logistics aims to ensure the halalness of the products along the flow in the Supply Chain. Halal Logistics is growing because of the increasing level of consumer awareness, not only of Halal products, but also the Halal Logistics process or Supply Chain.

According to Hasanuddin Yasni as Executive Director of Indonesia Chain Cooling Association, the fishing industry is still stagnant this year. Therefore, the government through the Ministry of Marine Affairs and Fisheries created cold storage program for storage. If there is a drive from the government, it could be the trigger for the private sector to make a similar business. This year, the processed chicken business is also growing significantly and requires cold storage up to 150,000 tons. Other industries such as frozen foods such as processed meat, ice cream, dairy products can also increase cold storage business opportunities to 350,000 tons. However, the industry that became the key to the development of cold storage business is the seafood or seafood products (Indonesia, 2003).

The year 2017 will be the period of venture for cold storage business growth. Since 2015 and continuing into 2016, this business only grew by about $5 \%$ due to slowing economic conditions. This year, it is predicted that the cold storage industry could grow to $10 \%$. By 2018, the cold storage business will also grow rapidly driven by several factors, one of which is the entry of new investors. Information on the market revealed that there are already some investors especially Singapore who are interested to enter the cold storage rental business. Thus, the chances of growing in 2018 will be greater. Beforehand, this fish storage was done by traditional fishermen method by utilizing ice blocks only. This method of preservation has a negative impact, such as the conditions of many fish are wasted, fish prices fall and price disparity. Based on researches in some locations, the existence of cold storage providers can make the price disparity up to $67 \%$. In here, 
Logistics entrepreneurs and Supply Chain can try their luck in Bonded Logistics Center business by applying Cold Chain and Halal Logistic concept.

A product is called a Halal product when it is in accordance with Islamic Shari'a. Halal is everything that the Shari'a permits to consume. "And Allah hath made for them all good and forbidden for them all that is evil." (Surat al-A'raf [7]: 157). "O people, eat what is lawful again from what is best on earth." (Sura al-Baqarah [2]: 168). (Mawlani Sher Ali, 2004)

Referring to Islamic Shari'a, Halal criteria are: (1) Halal substance is Halal product according to its substance is product from its basic is Halal to be consumed, and has been determined halal in Alquran and Hadith, (2) Halal way of obtaining it, the products were obtained in a good and legitimate way. The product will be haram if the way to get it is by way of violance because it can harm others and prohibited by the Shari'a, (3) Halal way of processing, which is originally Halal products and will be haram if the way of processing is not in accordance with the religious shari'a. There are so many products that are halal, but because of the improper processing cause the food to be haram. The third criterion requires the existence of a Halal product process, which includes a series of activities to ensure Halal products including the provision of materials, processing, storage, packaging, distribution, sales, and product presentation.

The Bonded Logistics Center is well suited to be applied in Cold Chain activities with Halal concept as Bonded Logistics Center is a multifunction warehouse that can store goods to support cosmetics, food and beverage industries. Cold Chain with Halal Logistics concept is proposed to enter because there are some benefits including: (1) Flexibility in taxation and customs where goods imported from abroad to PLB are not the subjects to import duty and import tax, (2) Flexibility of goods; goods that are imported into PLB can be from abroad, domestic, free area, and other special areas, (3) Flexible lifetime in the PLB can be stored for 3 years, (4) Flexibility of activities in the PLB also allowed to do simple works such as 
packaging, cutting, and other simple activities as long as they are not the activities of manufacture (production), (5) Flexibility of ownership of goods; goods that are dumped in PLB should not be owned by PLB entrepreneurs but may also goods owned by overseas suppliers (consignment), goods deposited from domestic goods owners or overseas goods owner, (6) Flexibility of restricted provisions is not enforced upon entry, (7) Flexibility of origin and destination of goods (one to many, many to one, many to many).

The most strategic location to develop Bonded Logistics Center that applies Cold Chain and Halal Logistics is in the area around the port or region not far from the port as a place of processing. The area which is about 50-100 kilometers from the port is still prospective to run this business especially if its location is still in Java Island.

The goal of Cold Chain and Halal Logistics is incorporated into PLB is to ensure Halal product along the flow in its Supply Chain with lowpriced and efficient Logistics, distribution and support the growth of domestic industry to meet the needs of targeted industries, to provide access to raw materials for import and export access to small-medium enterprises.

This Halal Logistics business is opened to all religions, not for Moslem only. To develop Cold Chain and Halal Logistics in PLB will need support and active role from Indonesian government, PLB entrepreneurs, and other stakeholders in order to improve national products competitiveness with Halal Logistics system. The government must prepare the Human Resources as business actors, with the paradima changing very quickly and its innovation sustainable is a necessity, modern organizations must put employees as assets, this is a major issue that must continue developed (Lesmini, Purwanto, \& Trisakti, 1969). The government needs to support Logistic actors in Indonesia to implement and obtain "Halal Logistics" certification so that they can play a role in mastering the halal supply chain of halal products in the world and encouraging Indonesia to become the Hub of Halal products. As it is known, Halal products are now 
getting prestige in some countries because the needs of the Moslem community of the world are so great.

\section{Conclusion}

Based on the information from research data, it can be concluded that Indonesia has the vast opportunity to become the Hub of Cold Chain and Halal Logistics business. PLB can help establishing Indonesia as the Hub of Cold Chain and Halal Logistics business. To establish these opportunities, it needs a blue print from relevant government agencies on infrastructure, education for human resource, Cold Chain operational handling and the concept of Halal Logistics. The government can establish and socialize a Bonded Logistics Center program with the "Halal Logistics" certification to gain more and open to the public with the aim of widely developed ability of national Logistics actors to value added needs for distributing, controlling and supervising Halal products to end users. Definite education is also needed to set up awareness for this industry to support Indonesia on becoming the Hub of Cold Chain and Halal Logistics business.

\section{References}

Direktur Jenderal, B. dan C. PER-01/BC/2016 tentang Tata Laksana Pusat Logistik Berikat (2016). Jakarta.

Edi, D. W. (n.d.). Biaya Logistik Dan Kelancaran Pengiriman Logistic Costs and the Good' S Delivery, 3(2), 227-243.

Hanafi, Y. N. (2017). LOGISTICS \& TRANSPORTATION: Halal Logistics.

Indonesia, L. A. (2003). Cold Storage, (April 2017), 40-46. https://doi.org/10.1295/kobunshi.49.387

Kementerian Keuangan. PMK-272-Tahun-2015 tentang Pusat Logistik Berikat (2015). Jakarta.

Lesmini, L., Purwanto, B., \& Trisakti, S. (1969). Ekonomi Maritim \& Sumber Daya Manusia Indonesia, 372-389.

Mawlani Sher Ali. (2004). The Holy Quran, Arabic text and English translation. Holy Quran.

Miles, M. B., Huberman, M. a, \& Saldana, J. (2014). Drawing and Verying Conclusions. Qualitative Data Analysis: A Methods Sourcebook, 275-322. https://doi.org/January 11, 2016

Raden Didiet Rachmat Simarmata, J. H., \& Len Togas, N. (2015). Study on The Cause of Stock Out of Logistic Installation in Harapan Kita Hospital. Jurnal Manajemen Transportasi \& Logistik, 2(1), 79-92.

S, T. I. H. (n.d.). Multimoda Dalam Mewujudkan Visi Logistik Indonesia 2025, $69-84$.

Tieman, M. (2011). The application of Halal in supply chain management: in-depth 
interviews. Journal of Islamic Marketing, Vol. 2 Iss: 2, pp.186 - 195.

Umagapi, B. W., Manajemen, S. T., Trisakti, T., Amonalisa, S., Manajemen, S. T., Trisakti, T., ... Trisakti, T. (2016). Bongkar Muat General Cargo the Documents Service Quality and the Speed, 3(3), 379-386.

Widhiatmoko, B. (2017). HALAL LOGISTICS \& COLD STORAGE. 